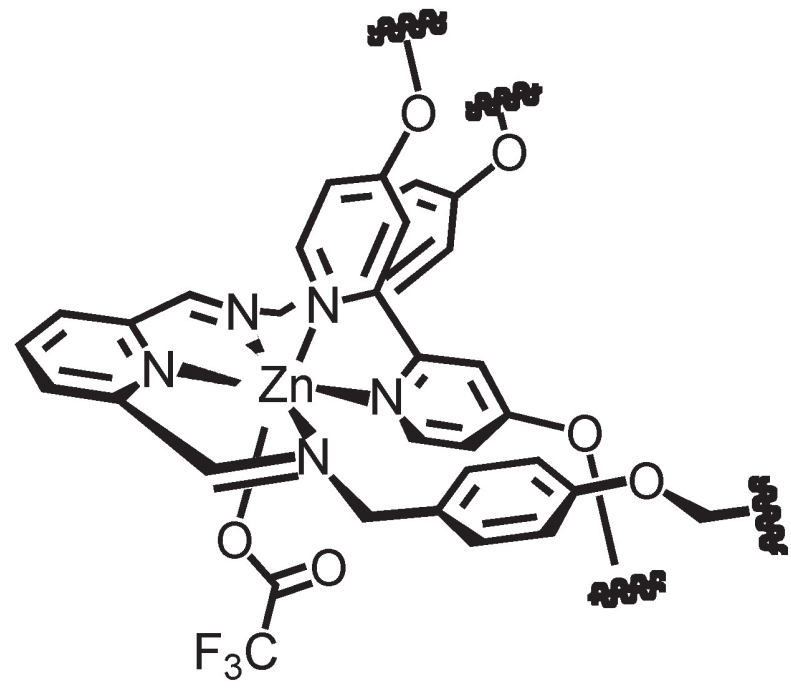

Fig. 2 Partial structure of 4.

ロモンの結び目 $\mathbf{6}$ を溶液に溶かして、質量分析をおこな うとボロメアンの環 $4 、 5$ に帰属される分子イオンピーク も観測されることから、溶液中ではこれらの超分子の間 には平衡が存在することもわかる。したがって実際に得 られたソロモンの結び目 $\mathbf{6}$ は速度論支配生成物が結晶化
したものである。このように同じ基質で同様な反応をお こなった場合でも、鋳型として用いる金属のわずかの差 によって得られる生成物が異なる理由は現時点では明確 でない。しかし今後、より多くの種類の金属を鋳型とし て検討することで、これまででは合成困難だった絡まり あいを有する化合物が数多く合成できる可能性がある。

以上のようなボロメアンの環やソロモンの結び目が本 質的に有する構造は興味深いが、最近ではボロメアンの 環にアンカーを導入し、これを金表面に導入することで、 デバイス作成とその評価も行われている4)。今後、分子 性化合物のみならず超分子化合物も、このような素材の 選択肢となることが期待される。

\section{引用文献}

1) C. Mao, W. Sun, N. C. Seeman, Nature, 386, 137 (1997).

2) K. S. Chichak, S. J. Cantrill, A. R. Pease, S.-H. Chiu, G. W. V. Cave, J. L. Atwood, J. F. Stoddart, Science, 304, 1308 (2004).

3) C. D. Pentecost, K. S. Chichak, A. J. Peters, G. W. V. Cave, S. J. Cantrill, J. F. Stoddart, Angew. Chem. Int. Ed., 46, 218 (2007).

4) G. D. Scott, K. S. Chichak, A. J. Peters, S. J. Cantrill, J. F. Stoddart, H. W. Jiang, Phys. Rev. B, 74, 113404 (2006).

\title{
自発的な配位高分子サブミクロン粒子の形成 Spontaneous Formation of Coordination Polymer Submicron Particles
}

\author{
九州大学大学院工学研究院応用化学部門 西藪 隆平 \\ Department of Chemistry and Biochemistry, Graduate School of Engineering, Kyushu University Ryuhei Nishiyabu \\ Received: July 21, 2007
}

\begin{abstract}
Spontaneous formation of submicron sized coordination polymer particles through self-assembly of metal ions and ligands has been reported by several research groups in the last few years. In this article, preparation of those particles and their characteristic features such as fluorescent, redox, and catalytic properties were described.
\end{abstract}

金属ナノ粒子や量子ドット等に代表されるナノ粒子は、 その大きさや形に依存してバルクの物性とは大きく異な るナノサイズ特有の性質を示すため、ナノテクノロジー の基幹材料として応用されている。配位高分子はその構 成要素である金属イオンおよび配位子の種類および組み 合わせによってさまざまな機能を発現することからナノ

連絡先著者名: 西藪 隆平

連絡先： 819-0395 福岡市西区元岡 744 番地

九州大学大学院工学研究院応用化学部門

Tel: 092-802-2836 Fax: 092-802-2839 Email: ryuheitcm@mbox.nc.kyushu-u.ac.jp Corresponding Author: Ryuhei Nishiyabu

Address: Moto-oka 744, Nishi-ku, Fukuoka 819-0395, Japan

Keywords:Nanoparticle, Submicron particle, Coordination polymer,

Spontaneous formation, Metal complex, Self-assembly
粒子の素材として極めて魅力的である 1,2$)$ 。従来、配位 高分子からなるナノ粒子を合成するためにはエマルジョ ンや高分子、タンパク質、無機ポーラス材料といったテ ンプレートあるいは粒子保護剤を用いる必要があつたが 1,2)、近年、ある種の配位子と金属イオンが自発的にサブ ミクロンサイズの配位高分子粒子を形成するという報告 がなされた (Fig. 1) $)^{3)}$ 。本稿ではこのような配位高分子サ ブミクロン粒子の自発的形成に関する最近の研究を紹介 する。

Oh と Mirkin は配位子 $\mathbf{1}$ と酢酸亜鉛を含むピリジン溶 液にジエチルエーテルを少しずつ加えていくと、直径が 約 $190 \mathrm{~nm}$ の球状配位高分子サブミクロン粒子が生成する ことを見出した (Fig. 1) 3)。得られたサブミクロン粒子は 種々の溶媒に安定に分散し、ビナフチル配位子由来の蛍 光特性を示した。また、彼らは貧溶媒の添加速度や種類 を変えることで粒径の制御を行っている。この報告から 間もなく、配位高分子粒子の自発的形成に関する研究が 相次いで報告された。Dong と Wang らは $p$ - フェニレン ジアミン水溶液に等モルのへキサクロロ白金 (IV) カリウ 
ムを含む水溶液を添加することによってサブミクロンサ イズの単分散球状配位高分子粒子を得ている 4)。本実験 において $p$-フェニレンジアミンのかわりに $o$-および $m$ フェニレンジアミンを用いたところ粒子の形成はみられ ず、配位子の構造が配位高分子粒子の形成に大きく寄与 していることが示唆された。また、得られた配位高分子 粒子の分散液に水素化ホウ素ナトリウムを添加すると白 金 (IV) の還元に伴って粒子が溶解したことから、本粒子 が中空カプセル合成のテンプレートとして有用であるこ とが示された。また、Maeda らは配位子 2 をはじめとす るフェニルエチニルスペーサの両末端にジピロメタン部 位を有する配位子が亜鉛イオンと配位高分子を形成する ことによって蛍光性のサブミクロン粒子を与えることを 報告している (Fig. 2) $)^{5)}$ 。本実験ではスペーサの構造や用 いる溶媒を変えることによって半球やベル型、ゴルフボ ール型などの構造体が形成することが見出されており、

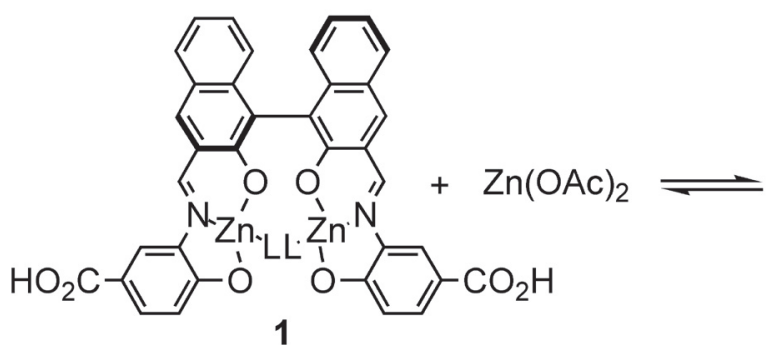

$L=$ pyridine, water

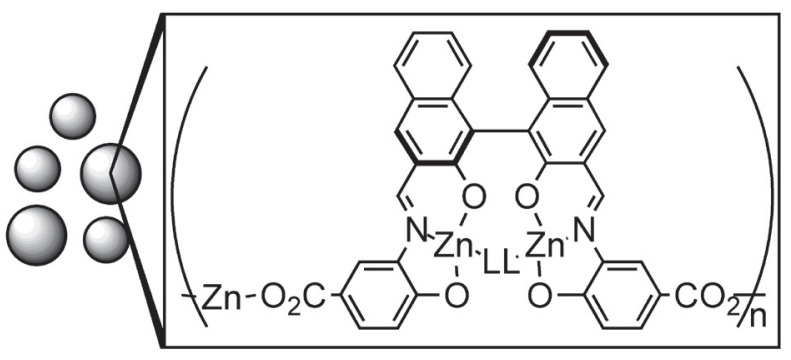

Fig. 1 Spontaneous formation of submicron sized coordination polymer particles.
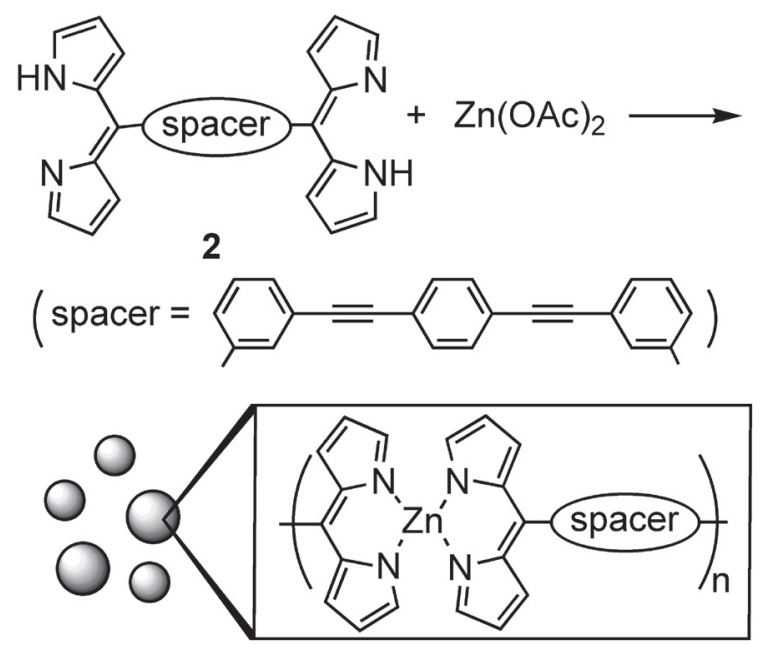

Fig. 2 Coordination polymer submicron particles formed from dipyrrin dimer ligand and $\mathrm{Zn}(\mathrm{OAc})_{2}$.
粒子の大きさだけでなく形を制御することにも成功して いる。一方、このような配位高分子サブミクロン粒子を 反応触媒として用いた研究も報告されている6)。Son お よび Sweigart らは $\left[\left(\eta^{6}-1,4-\right.\right.$ ヒドロキノン $)$ ロジウム $(1,5-$ シクロオクタジエン)] (3) とアルミニウムイソプロポキ シド $\left(\mathrm{Al}\left(\mathrm{O}^{i} \mathrm{Pr}\right)_{3}\right)$ からなる配位高分子サブミクロン粒子を 調製し、その触媒能について検討している (Fig. 3)。フエ ニルアセチレン $(\mathrm{PA})$ の重合反応において、触媒 3 はほと んど立体選択性を示さないのに対し、配位高分子サブミ クロン粒子は $90 \%$ 以上の割合で cis- ポリフェニルアセチ レン (cis-PPA) を与えた (Fig. 3)。触媒反応機構の詳細に ついては言及されていないが、触媒反応における立体選 択性の向上が触媒 3 と $\mathrm{Al}\left(\mathrm{O}^{i} \mathrm{Pr}\right)_{3}$ の複合化あるいはその複 合化によるサブミクロン粒子の形成に起因していること は明らかである。本稿で紹介した自発的な配位高分子粒 子の形成は、その合成において添加物や煩雑な精製操作 を必要としないため、簡便な配位高分子ナノ粒子の調製 法として期待される。これまで報告されている配位高分 子粒子の多くはサブミクロンサイズであるが、その形成 機構が解明されることによってナノ粒子の調製も可能と なろう。今後、本手法を用いることでどのような特性を もつた配位高分子ナノ粒子が見出されるかに興味がもた れる。

\section{引用文献}

1) T. Uemura, S. Kitagawa, Chem. Lett., 132 (2005).

2) M. Kurihara, Bull. Jpn. Soc. Coord. Chem., 48, 34, (2006).

3) M. Oh, C. A. Mirkin, Nature, 438, 651 (2005).

4) X. Sun, S. Dong, E. Wang, J. Am. Chem. Soc., 127, 13102 (2005).

5) H. Maeda, M. Hasegawa, T. Hashimoto, T. Kakimoto, S. Nishio, T. Nakanishi, J. Am. Chem. Soc., 128, 10024 (2006).

6) K. H. Park, K. Jang, S. U. Son, D. A. Sweigart, J. Am. Chem. Soc., 128, 8740 (2006).
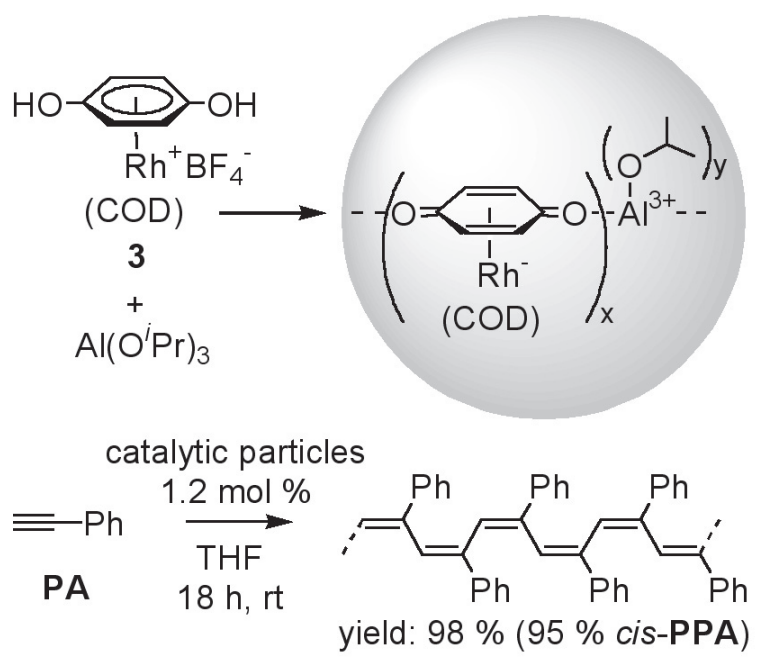

Fig. 3 Synthesis of coordination polymer submicron particles and their catalytic property. 